TURIZAM

Volume 13

Issue 2, 69-74 (2009)

\title{
"Controlled and Managed Adventure" - Croatian Approach to the Development of Nautical Tourism in Croatia?
}

\author{
Srećko Favro** \\ Iva Saganić** \\ Zvonko Gržetić*
}

Received: July 2009 | Accepted: November 2009

\section{Abstract}

Ecological preservation of intact nature, of mystical and genuine Mediterranean cultural environment is the most crucial requirement for the development of nautics, but also for upgrading present capacities and complementary activities in the Adriatic. At the same time, preservation of natural beauties, intact bays, but also development of sufficient amenities in marinas for overnight stay, services and entertainment, requires such development strategy that will balance and show consideration for all these aspects. That could be called a "discretely controlled and managed adventure" that will always have the price it has deserved. One has to bear in mind, though, that boaters primarily come in order to be at sea, that a marina is a necessary element of navigation, and that boaters want to spend the major part of their time aboard, in the sphere of "adventure". The leading part in implementing this decision lies with government bodies that have to be able to adapt the boaters' desire for high services to local specific aspects. Nautics has to be administered, but administrative and expert entities have not proved to be the best solution. It may be assumed that the development one of the institutions into a body permanently responsible for monitoring, analyses and expert proposals could be a solution that would find place in the current vacant space between performers (mostly private companies) and administration (few and inadequately qualified). Also, strict standards have to be determined and controlling system established, so that attractiveness is kept, while sustainable and controlled development of the littoral and islands is enabled.

* Hrvatski hidrografski institut, Zrinsko-frankopanska 161, Split, Hrvatska

** Zadarska privatna gimnazija, Kraljskog Dalmatina 4, Zadar, Hrvatska

- Corresponding author: srecko.favro@adriatic-expert.hr 


\section{Introduction}

Croatian littoral has a unique attractiveness of the coast and islands and is the geographical basis for the development of nautical tourism which is indisputably authentic and particularly recognised Croatian "tourism product". Moreover, one may say that is nautical tourism that is genuine and most prominent trade mark of Croatian tourism, especially of its most important and most valuable part - the sea and its unique coastal and insular areas.

Although, according to the American magazine "Cruising World", the Adriatic and the Caribbean are the best nautical areas in the world, the accepting capacities of nautical tourism (marinas, berths and anchorages) and services are still at the level of market needs of over a decade ago. We have to be aware that we have not used the potential that could stimulate the complete economic development of coastal and insular Adriatic, and consequently of Croatia (Favro, Saganić, 2006-I).

\section{Advantages That Croatia Has for Further Development of Nautical Tourism}

Eastern Adriatic coast has distinctive comparative advantages for the development of nautical tourism, and the following elements need to be pointed out (Favro, Saganić, 2007):

- Indentedness of the coast, favourable climate, suitable winds of medium power, a number of protected bays and inlets,

- rarity natural resources, beautifully landscapes,

- diversity of natural, coastal and submarine landscape,

- good arrangement of small and large places and of ports and harbours that allow for cruising in small vessels,

- ideal geographic position suitable for quick arrival from any part of Europe.

As can be seen, there are two main groups of comparative advantages of the eastern Adriatic coast: suitable location in the Mediterranean that is growingly becoming a powerful European and world tourist centre and a particular advantage of this coastal area, and favourable climatic, geomorphologic and other features (Luković, 1995).

\section{Goals}

The main global goal refers to stimulating the development of the coast and islands and preserving the clean sea and intact nature. This is closely connected to establishing a system that is monitored, controlled and developed (Favro, Saganić, 2006-II).

In order to reach that goal, it is necessary to undertake several actions that will allow for the development of a recognisable brand of the Adriatic, fast development of certain segments in nautics, and preventing uncontrolled construction of thousands of berths and ending the devastation of the coast and of the growth of illegal charter (Favro, Glamuzina, 2005).

The first step towards the realisation of that goal is the implementation of the Strategy of development of nautical tourism, led by a professional and qualified institution that will define the necessary conditions and methods for realising the principal goal (HHI, SRNTH, 2006). 


\section{Factors of Development of Nautics in the Adriatic}

Croatia has the territory of $56,538 \mathrm{~km}^{2}$ of land and $60,000 \mathrm{~km}^{2}$ of sea, five national parks on the coast and islands, two national parks in the immediate hinterland, very rich cultural and historical heritage (Dubrovnik, Roman emperor Diocletian's Palace in Split, a series of museum towns like Zadar, Šibenik, Pula, Trogir, Korčula, Poreč) and a long list of other natural, cultural and historical assets. However, branding and marketing activities have not been sufficient so far (Jadrešić, 1997). All the above assets can be considered as development potentials and prospects, but the current approach does not guarantee that they will be used (Šimičić, 1994).

During the present development of tourism over $90 \%$ of the total turnover has been related to natural attractiveness and ecology element, which is similar for nautical tourism as well. At the same time, possibilities of small, picturesque coastal towns, with their Austro-Hungarian ports, local features and historical details have not been taken into consideration. This is where our chances and potentials lie (Čaldarović, 1992).

Table 1. The marinas capacity in the Republic of Croatia for period of 1993-2007. and the increased index

\begin{tabular}{|l|r|r|r|r|r|r|r|r|r|r|r|}
\hline Capacity & 1993 & 1995 & 1997 & 1999 & 2001 & 2003 & 2004 & 2005 & 2006 & 2007 & $\begin{array}{c}\text { Indeks } \\
2007 / 1993\end{array}$ \\
\hline Marinas & 37 & 40 & 42 & 55 & 66 & 75 & 83 & 84 & 95 & 95 & $257 \%$ \\
\hline
\end{tabular}

From the above diagram, the growing trend of capacities can be observed, but the question is at which places and with which effects? There is a possibility that some parts of the coast become congested with vessels, while some other parts may still be considered undiscovered. Strategic approach to the development of nautical tourism in Croatia has to contain conditions which need to be satisfied in the environment in order to avoid such situations. Some of the conditions and requirements are:

- To realise an integral development programme for the entire Adriatic aquatorium, with global decision of the purpose of particular parts, and specification of the holders of the development of nautics (Kovačić, Favro, 2006).

- To establish legal basis for coordination of general social, local and private interests in the further development of nautics. Simultaneously, it is necessary to take into account possibilities of the wider community and to coordinate the development of complementary activities. At the same time, local groups will be able to take independently their path to realise the agreed goals, although they will surely have to confront with individual interests. Hence, it is necessary to stimulate the following:

- Education of the local inhabitants aimed at receiving higher category tourists, especially relating to providing services,

- Establishing mega marinas in the proximity of airports (mostly land marinas situated in already devastated areas, such as Pomer - Pula, Borik - Zadar, towards the seaport, southern part of the Krka estuary, the Bay of Kaštela, Rijeka Dubrovačka) and areas of attractive, intact Mediterranean harbours (most part of the Adriatic with satellite marinas).

- Founding a quality data base and access to individuals that are capable to explain to boaters the opportunities of nautical cruising in Croatia. Current Croatian tourist brochures are not satisfactory, neither the qualifications of professionals in tourism, as they lack considerable aspects. A boater plans their voyage that is connected to their motives, interests and needs charts to decide on the routes, and to general tourist information. 


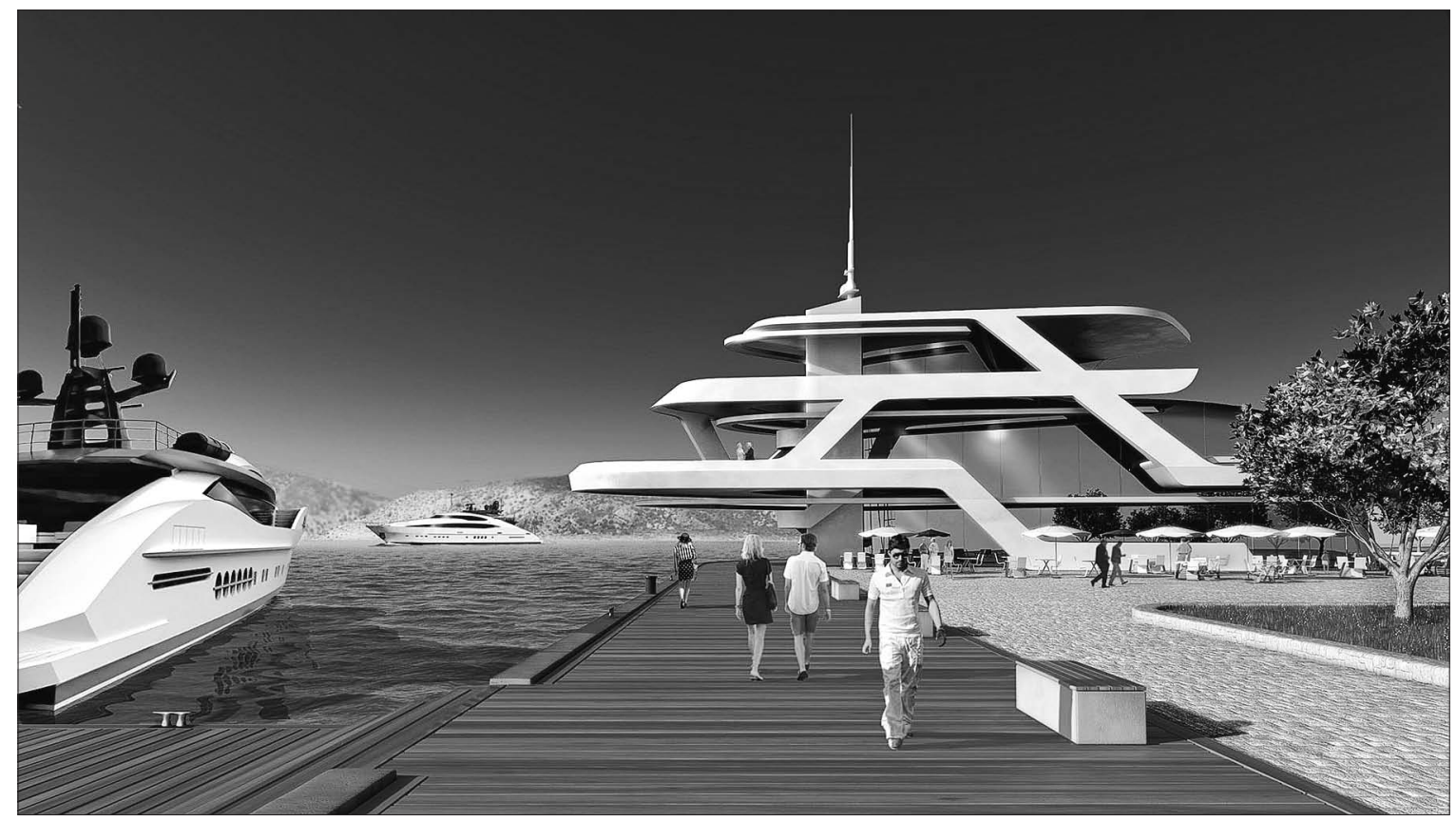

Figure 1. The project of new marina accompanied by a yacht club and marine village on the island of Šolta in Croatia

- Marketing - in terms of introducing new nautical products to the market and their successful launching. The mere definition illustrates the difference, since the results we have achieved in nautics have been realised only owing to natural beauties. It is necessary to design our global presentation in a conceptual and considered manner, at the same time preventing egotistic strikes of individuals and devastation of cultural heritage.

The strategic approach to the development of nautical tourism includes a number of tasks:

- To specify protected areas which will, due to their exceptional value (national parks, nature parks), be defined as destinations for daily visits by organising berths at berthing places and anchorages without overnight stay (Kornati, Krka, Mljet, etc.), (Favro, Project of the Government of the Republic of Croatia, 2002).

- To valorise potentials of interesting localities on the coast by implementing multi-criteria analysis of a particular area. Multi-criteria analysis could be conducted by collecting data from competent government and expert institutions, and would be the basis for designing a proposal for increasing nautical tourism capacities:

- Geographic and meteorological properties of the locality,

- Environmental values,

- Maritime navigational properties,

- Current impacts to the environment and the risks,

- Infrastructure: electricity, water supply and telecommunications,

- Traffic connectivity,

- Physical plans coverage,

- Demand of the market - areas of intense nautical tourism,

- Possibilities for the development of complementary activities - employment,

- Other parameters. 
The obtained data would determine the potential of a particular area for the construction of nautical tourism capacities in view of geographic, maritime, ecologic, social and economic properties of the locality.

- To prepare a comprehensive presentation of the obtained data to local communities, initiators of the construction of a particular nautical object (marina, harbour), accepting the general national decisions as common views. After the communities and towns expressed their interest and considerations, and the future object has been complied with the physical plan of the county, the project will be designed, with the assistance of the government that will implement the realisation of the strategy of nautical tourism.

The initiative and vital influence in the realisation of a particular project (selection of the location and of the type of the capacity: anchorage, berthing, harbour, marina) will be at the local self-government that will be assisted by the Government and the ministries through the competent government and expert maritime institution.

The design of the project and the realisation of the construction will be effected by implementing recognised international category quality standards for nautical tourism ports (for instance Loyd's), evaluating the quality level of:

- Additional facilities,

- Technical equipment,

- Services,

- Security from theft,

- Protection from extreme weather conditions and fire,

- Possibility for berthing during winter.

The Government should require conformity of works of a company with international standards:

- Environment management system ISO 14000

- Environment management system ISO 9000

This would simplify controlling the level of services of a particular subject, and ensure the control of the impact to the environment.

The supervision of the quality implementation of the established standards would be ensured through certificates issued by authorised international certifying institutions and through the national inspection bodies.

The safety of navigation would be ensured through the Coast Guard service and Captain of the harbour's offices, and the permanent control of ecology situation at a locality would be organised by ecological patrols, voluntary maritime guards, etc.

\section{Conclusion}

This review does not pretend to assume the role of a more substantial document that would be an elaboration of the strategy, but offers ideas and gives suggestions for the production of detailed documentation accompanying the Strategy of development of nautical tourism. At that point, the government is present through the institutions of the systems as the superior body whose expert institution will propose and direct the development of nautics in the Adri- 
atic. Although it seems a hard work, especially particular projects already in progress, on longterm basis it will be beneficial not only for us but also for future generations.

\section{References}

Čaldarović, O. (1992). Marine u području jadranske obale i njihove socijalno-ekološke posljedice, časopis Socijalna ekologija, Vol.1, No.1, 51-61.

Favro, S., Glamuzina, N. (2005). Contemporary problems of Nautical Tourism Development in Croatia, Promet, Portorož, Trieste, Zagreb, Žilina br. 2/2005, 107-112.

Favro, S., Saganić, I. (2006). Komparativne prednosti hrvatskog litoralnog prostora za razvoj nautičkog turizma, Akademik Josip Roglić i njegovo djelo, Zbornik radova s medunarodnoga znanstvenog skupa, Makarska, 387-402.

Favro, S., Saganić, I. (2006). Sustainable Development of Nautical Tourism in Croatia. "New Perspectives and Values in World Tourism E Tourism Management in the Future", TurkKazakh International Tourism Conference, Alanya, Turkey, 2006. Book 1, 602-620.

Favro, S., Saganić, I. (2007). Prirodna obilježja hrvatskog litoralnog prostora kao komparativna prednost za razvoj nautičkog turizma. Geoadria. vol.12 No.1, 59-81

Hydrographic Institute of the Republic of Croatia and partners (2006). Study of nautical tourism development of the Republic of Croatia, Project of the Government of the Republic of Croatia

Jadrešić, V. (1997). Hrvatski nautički turizam - između danas i sutra, Turizam, vol. 45 No. 11/12/97., 111-123.

Kovačić, M., Favro, S. (2006). Physical Plans in Managing Sea and Coastal Area, $25^{\text {th }}$ International Conference on Organizational Science Development, Portorož.

Luković, T. (1995). Marketing - koncepcija razvoja nautičkog turizma Hrvatske, Ekonomsko istraživački biro, Split.

Srećko F. (2002). Razvoj sustava turističkih lučica na hrvatskim otocima, Projekt Vlade RH.

Šimičić, V. (1994). Priobalje i podmorje Jadrana u razvojnoj strategiji hrvatskog turizma, Zbornik izlaganja, okrugli stol, za ACZS ‘95 